\title{
Mechanisms of Ethical Control and Effectiveness of Governance
}

\author{
Bouhellala Souad \\ Algerian Nationality, a professor lecture b, Enterprise Taheri Mohammad Bechar University
}

\begin{abstract}
Summary: This work aims to demonstrate that the concept of governance in various institutions requires several conditions, the most important to enjoy the management culture that allows to realize and understand the responsibilities of the parties concerned on the one hand, and the ability to achieve the planned objectives on the other hand, and this cannot be achieved unless characterized by the various forces of human resources, ethical aspects necessary to do so, especially when it comes to operations control and internal audit and external for this concept. So what's the relationship between ethics and oversight committees' corporate governance? We answer the question after a study of the general framework of corporate governance, accounting and financial dimension of corporate governance and its relationship to the ethics of human resources, control mechanisms and the role of audit committees in corporate governance.
\end{abstract}

Keywords: ethics, control mechanisms, corporate governance, internal audit and external, human resources

\section{Introduction}

The new method of corporate governance helps in the economic performance and competitiveness support, attracting investments and the economy in general, through the strengthening of transparency element in all transactions and operations of the institutions, and procedures for financial accounting and auditing as can adjust elements of corruption at any stage, improvement and development of enterprise management, help managers and board of directors to build a sound strategy, and to ensure that decisions based on sound foundations, leading to increased performance efficiency, This requires the availability of positive values and individual moral obligations and collectively, supported by many different institutions, and financial institutions as a basis to ensure good governance, stemming from a fundamental perspective and an ethical and nonutilitarian and material only, and even aims as well as the ability to successful strategic decision-making.

\section{Problem Of The Study}

It is agreed that the main causes of the collapse of a lot of institutions and economic companies is the lack of application of accounting principles and the lack of disclosure and transparency and do not show the real data and information that reflect the real financial situation of these economic institutions, This was reflected in a range of negative effects And most importantly, the loss of confidence in the accounting information, And therefore this information is lost recipe good feature. And from here we can ask the question: What is the relationship between ethics committees and oversight by internal audit and external corporate governance?

The importance and objectives of the study:

We increased our attention to the concept of corporate governance and the role of ethics committees and internal controls its own foreign, It became the main pillars that must underpin economic institutions, especially since a lot of organizations and bodies confirmed the advantages of this concept and encourage its application. And we will reach to the need to lend moral side of workers in each activity for the governance of individuals

\section{Methodology}

The general framework of corporate governance, the financial dimension of accounting and corporate governance and its relationship to the ethics of human resources, control mechanisms and the role of audit committees in corporate governance.

\section{The First Axis: The General Framework Of Corporate Governance}

\section{Definition Of Corporate Governane}

Is to involve all the forces and the concentration of all efforts towards the progress of the institution in order to make it run correctly and properly, they are a complete system of authorities and procedures, and control internally and externally created to follow up on economic units management, (Ahmad Sharaf, 2002) in order to protect all stakeholders this definition on the focus ethical, where he pointed out that the objective of governance is to protect the rights of all parties of the shareholders and creditors, workers, suppliers and lenders ............ etc stakeholders Corporation 


\section{Terms Corporate Governance}

To realize and support the governance system in the enterprise, we must provide a range of conditions, including: transparency, accountability, responsibility, clarity, independence, and the existence of an audit committee, (Obaid Al-Mutairi, 2004) and these elements means the presence of laws and regulations clarify the rights of shareholders, see clearly defined milestones strategic enterprise with tools that ensure the realization of this vision, through translated into plans for short- and long-term goals, and clear regulatory structure determined by the authorities and responsibilities, produced by a group of systems such as the rules of procedure of the institution, the internal control system, and then after that, and most importantly accounting system responsibility provides a range of financial and non-financial indicators needed to evaluate the performance and accountability, How to review the presence of its powers to ensure that it has the right to exercise its supervisory role on the agenda of internal and external references

\section{The Importance Of Governance For The Foundation}

Governance lay the foundations of the relationship between the property managers and board of directors and shareholders

- Governance describes the rights and duties of each party be allowed to exploit the possibilities better exploit ,And thus the economic efficiency of the institution goes up,

- Working on a regulatory framework within which to define the objectives of the facility and ways to achieve them ; Also lead to the opening up to the global capital markets

- governance increase the number of investors to finance expansion projects;

- The governance rules applied increases the confidence of investors

4. Gols of Corporate Governance

The new method of corporate governance helps in the economic performance and competitiveness support, attracting investment and the overall economy through the following means

- Strengthen the transparency element in combating transactions and operations of the institutions and procedures for financial accounting and auditing as you can adjust the elements of corruption at any stage.

- Improvement and development of enterprise management and help managers and board of directors to build a sound strategy, and ensure that the merger or control decisions based on sound foundations, leading to increased performance efficiency.

The Seond Axis: Accounting And Financial Dimension of Corporate Governance And Its Relationship To The Ethics Of Human Recourses

1. The Importance of the Human Element In The Enterprise

Every increase in the volume of business and activities required by the project followed by the modification of the structures, and sometimes a change in their design, and human resources management is the beating heart of modern management because they assume the functions and tasks reinforce its position in the organizational structure of the institution and make it a means of survival and permanence in activity and achieve success.

\section{Relationship of Accounting Information Enterprise Governance And Human Resources}

It is understood that the governing institution is a financial accountant, and is known also that the person who controls the accounting information and Finance is a financial accountant, too, and this is what leads him to convert some of the wealth of these institutions, which are supervised by to his own account to achieve its objectives in accordance with the legal ways or illegal satisfy his ambition, and in general, and this must be characterized by the qualities of accounting information is the appropriate, credibility, objectivity, utilitarian, inclusive.

\section{Objectives and functions of accounting}

- Accounting aims to keep full records, organized and permanent fiscal actions undertaken by the institution for reference when needed;

- The provision of data and information needed for planning and policy future periods; Various parties to the Foundation Media (managers, wage-earners, shareholders, banks, state, customers, suppliers), and facilitate the activities of the institution through the development of management, measurement and control instruments

- Provide the data necessary to tighten control over the work of the institution and keep their assets and information ; Help internal and external parties in decision-making and management of enterprise activity;

- Accounting allows assessment of competencies for economic and financial institution and risks. The posts of accounting are :

* Measurement Function: is interested in measuring the results of the financial operations of the institution

- Communication function: is concerned with Connect accounting information to third parties used for this information. 


\section{Scientific And Practical Training Based On Moral Grounds}

Accountant apply international accounting standards, so it must be qualified academically and practically, and in an ethical manner, and accountant today demands technical skills in certain fields, Such as banks, insurance companies and pension funds, tax and information technology.

According to the opinion of the employers, Accountant should be characterized by intellectual ability needed to work, and provides advice and not only limited to providing information, And requires it to take the necessary measures at schools, colleges and universities level, participation in national and international seminars and forums, Encouraging configuration in parallel with professional activity in the field of new accounting techniques.

\section{The Third Axis: Control Mechanisms And The Role of Audit Committees In Corporate Governance}

\section{The Concept of Control Mechanisms}

Means the overall control systems carried out by senior management and Board of Directors, in order to reduce the risks to the institution, particularly loss of reputation, and ensure the rights of the largest number of shareholder.

The control system provides two types of regulatory mechanisms:

\section{- The First Mechanism:}

It specializes in the mechanism of internal control by the Board of Directors, and the bodies of internal audit.

\section{- The Second Mechanism:}

It is concerned with external oversight mechanism through government regulations and legislation, media, competition, external audit.

\section{Regulatory Dimensions of Corporate Governance And Its Relationship With The Accounting Information}

It evidenced by extrapolation of the previous information that we can confirm the dimensions of the regulatory governance institutions, and supporting accounting information systems as follows:

- Accountability and accounting oversight

- Commitment to the application of Accounting and Auditing Standards

3.The Role of Internal Audit And Ethics of Internal Audit

Internal Audit will help to achieve its objectives and confirm the effectiveness of internal controls It works with the Board of Directors and the Audit Committee for the risk management and control In the corporate governance process by evaluating and improving the internal processes of economic unity, as well as the achievement of internal control as a result of independence and subordination to the Chairman of the Board and its contacts with the Chairman of the Audit Committee.

Ethics is a set of principles or values, and laws, regulations and religious sermons and public charters for professional groups such as accountants, and codes of conduct for different organizations. These principles are related to the profession and practice of internal audit, which is expected from internal auditors' application: support all of integrity, objectivity integrity, confidentiality, and efficiency.

4.The Role of The External Audit In Corporate Governance And Responsibility of The External Auditor

External audit is considered as an early warning bell for companies, Because it is a statement of financial and administrative distractions, By applying the rules of professional diligence and audit of the accounts of the company, Auditing and financial management systems and verification of assets This will lead to detect weaknesses and flaws in the company's management in a timely manner Thus we, we put the best ways to address the danger before it spread, We get rid of fraud and forgery by adopting external audit application This means for us Contribute to the establishment of corporate governance.

\section{The responsibility of the external auditor is:}

- Civil liability

- Criminal responsibility

- Responsibility of the public discipline

- Moral Responsibility:

\section{Conclusion}

The principle of transparency and disclosure is one of the most important pillars of a successful economy. Our economy cannot attract investment if there is not enough transparency in all sectors especially that Changing correct and accurate information for investors will push them to take a decision T. wrong.so, Investors are working to steer investments away, Application of the regulatory systems and procedures of the institution, are Always remain in need of moral codes of conduct. The strong ethical aspect must be emphasized as a basic document that works to support and activate the governance of our various institutions, thus maintaining stability and security. 


\section{References}

[1]. Ahmed Sharaf Abdel-Hamid, 2002 Governance and published financial reports of Egyptian companies, No. 2, Journal of Contemporary Business Research, Faculty of Commerce, South Valley University, Egypt, p. 223

[2]. Amin Ahmed Lotfi, 2007 Advanced studies in auditing and confirmation services, University House, Alexandria p. 21

[3]. Bahaa El Din Samir Allam, 2009 The Impact of the Internal Mechanisms of Corporate Governance on the Financial Performance of Egyptian Companies - Egypt's Implementation Study: Ministry of Investment, Egyptian Directors' Center, p. 8

[4]. Tarek Abdel-Al Hammad, 2006 Corporate Governance and the Global Financial Crisis, University House, Alexandria, p269.

[5]. Abeed Al-Mutairi, 2004, The Future of the Accounting and Auditing Profession, Challenges and Contemporary Issues First Edition Dar Al-Marikh Publishing and Distribution, Riyadh: p. 1

[6]. Al-Fadl, 2007, Relationship between Governance and Value of the Institution, Jordan Case Study Volume 28, Issue 112, Economic Horizons Journal, UAE Chamber of Commerce, p. 25

[7]. Mohsen Ahmed Al-Khudairi, 2005 Corporate Governance, First Edition, Nile Group, Cairo, p. 21

[8]. Madani Ben Badhith, Mohamed El-Tohamy Ibrahim, 09 March 2005 The Algerian Foundation and the Challenges of Improving the Outstanding Accounting Performance of Organizations and Governments (World Conference on Performance, University of Ouargla, Algeria), p. 98

[9]. Nasser Dadi Adon, 2001, The Economy of the Foundation, Second Edition, Dar Muhammadiyah, Algiers, p. 236.

[10]. Nor eddine meziani and Faroum Mohamed saleh January 2010, International Accounting Standards and the Algerian Environmental Standards Application requirements, The first international forum on the new financial accounting system International Accounting Standards Experiences - Prospects of Challenges - 18/17 Institute of Economic, Commercial and Management Sciences, University of the Valley, Algeria p10

[11]. Nuri Munir, 2010, Human Resources Management, University Publications, p. 32

[12]. Bertrand RICHARD, 2003 "the dynamics of corporate governance", (Paris: Ed Organization, 2003$)$, p 01. 